\title{
ARTIKEL AUDIT SISTEM INFORMASI TATA KELOLA UNTUK MENGONTROL MANAJEMEN KUALITAS MENGGUNAKAN COBIT 4.1 DI PT.NIKKATSU ELECTRIC WORKS
}

\author{
Devi Cantika \\ 155100018 \\ Universitas Mitra Indonesia, Sistem Informasi \\ devicantika.student@umitra.ac.id
}

\begin{abstract}
ABSTRAK
Sistem informasi telah menjadi bagian penting dalam organisasi, terutama untuk organisasi bisnis yang berorientasi laba. PT Nikkatsu Electric Works adalah salah satu perusahaan yang membutuhkan tata kelola Sistem informasi. Tata kelola Sistem informasi perlu dievaluasi untuk menetapkan kondisi perusahaan dalam hal manajemen kinerja TI untuk mengontrol kualitas. Salah satu hal penting yang dapat membantu untuk mengevaluasi kinerja yang mendasari teknologi informasi adalah kerangka kerja untuk tata kelola Sistem informasi yang memberikan dasar untuk pengembangan tata kelola Sistem informasi berdasarkan COBIT. Analisis dan evaluasi dilakukan oleh kerangka kerja COBIT 4.1 pada domain ME1. Ini adalah pemantauan dan evaluasi kinerja teknologi informasi. Metode atau alat yang digunakan adalah perhitungan AHP. Hasil analisis adalah bahwa evaluasi tingkat kematangan dan kinerja TI berada pada level 2. Sedangkan tingkat harapan perusahaan berada pada level 4. Rekomendasi strategi dari 6 aspek atribut kematangan diperlukan untuk mencapai tingkat yang diharapkan.
\end{abstract} Kata Kunci: Tata Kelola Sistem Informasi, Untuk Mengontrol Manajemen
Kualitas PT.Nikkatsu Electric Works. 


\section{A. PENDAhuluan}

Peran teknologi menjadi penting bagi perusahaan, termasuk diantaranya PT Nikkatsu Electric Work. Sebagai perusahaan yang mengelola suatu alatalat, dengan tujuan utama (core business) yang tidak tergantung secara langsung terhadap kehandalan TI, namun efektifitas perusahaan dalam mengelola TI yang mendukungnya secara optimal dapat membantu perusahaan dalam mencapai tujuannya. Dalam melakukan pengukuran kinerja terhadap penggunaan dan pengelolaan TI suatu organisasi atau perusahaan maka ITGI merupakan lembaga yang melakukan pengaturan tata kelola TI memiliki standar tools / framework yang digunakan diantaranya COBIT (Control Objectives for Information and related Technology ), ITIL (The InfrastructureLibrary), COSO

(Commitee of Sponsoring Organization of the Treadway Commision), ISO/ IEC 38500 (The International Organization for Standardization ) dan sebagainya. COBIT ialah acuan / kerangka kerja untuk pengukuran dan pengendalian TI.

Kerangka kerja COBIT merupakan standar yang dinilai paling lengkap dan menyeluruh sebagai framework audit TI, karena dikembangkan berdasarkan aturan / prosedur internal perusahaan / institusi, sehingga saat dilakukan pengukuran akan sesuai dengan kondisi, aturan, prosedur kerja dan norma yang ada di perusahaan tersebut. COBIT telah dikembangkan secara berkelanjutan oleh lembaga profesional auditor yang tersebar hampir di seluruh dunia.

PT Nikkatsu Electric Work adalah perusahaan yang memproduksi alat-alat listrik seperti: Transformer, Ballast, PLadaptor, Lampu Hemat Energi (LHE) selain itu produk lainnya adalah stacking core Yamaha, Moric, dan Yasunaga. Dalam mencapai tujuan bisnisnya, perusahaan ini mempunyai faktor-faktor pendukung dalam setiap aktifitas proses bisnis yang berjalan, salah satunya adalah menjamin kualitas pada saat pembelian bahan baku, produksi, sampai bahan jadi, Peranan yang paling besar dalam menjamin kualitas adalah departemen logistik.

Departemen logistik merupakan inti dari perusahaan ini Sehingga menjadi pengaruh terbesar atau faktor utama dalam mencapai visi misi dan tujuan dari perusahaan. Ada beberapa bagian yang termasuk kedalam departemen logistik, salah satu diantaranya adalah inventory. Peranan inventory dalam perusahaan sangatlah penting yaitu untuk mengatur keluar masuknya bahan baku, baik itu bahan yang datang dari supplier maupun bahan yang sudah diproduksi dan akan dikirim.

Dalam menunjang kegiatan tersebut, inventori sudah didukung oleh TI yang berupa suatu sistem informasi inventori, namun seiring berjalannya waktu sering terjadi keterlambatan dan kesalahan yang terjadi. Namun akar dari itu semua dikarenakan masih rendahnya tingkat kepedulian manajemen terhadap penggunaan TI di PT Nikkatsu Electric Works khususnya dalam mengontrol manajemen kualitas. Oleh karena itu, perlu dilakukan suatu kegiatan audit tatakelola dimana dilakukan agar diketahui seberapa besar tingkat kematangan di perusahaan pada proses pengawasan dan evaluasi kinerja TI. Lalu setalah itu dibuat rekomendasi 
yang dapat diberikan untuk meningkatkan kinerja tata kelola TI yang sedang berjalan saat ini agar lebih baik dalam mendukung proses bisnis khususnya dalam manajemen kualitas.

Oleh karena itu, perlu dilakukan suatu kegiatan audit tatakelola dimana dilakukan agar diketahui seberapa besar tingkat kematangan di perusahaan pada proses pengawasan dan evaluasi kinerja TI. Lalu setalah itu dibuat rekomendasi yang dapat diberikan untuk meningkatkan kinerja tata kelola TI yang sedang berjalan saat ini agar lebih baik dalam mendukung proses bisnis khususnya dalam manajemen kualitas.

a. Identifikasi Masalah

Berikut identifikasi masalah sebagai berikut :

1.Masih rendahnya tingkat kepedulian manajemen terhadap penggunaan TI di PT Nikkatsu Electric Works khususnya dalam mengontrol manajemen kualitas.

2. Belum diketahuinya seberapa besar tingkat kematangan di perusahaan pada proses pengawasan dan evaluasi kinerja TI.

3. Belum adanya rekomendasi yang dapat diberikan untuk meningkatkan kinerja tata kelola TI yang sedang berjalan saat ini agar lebih baik dalam mendukung proses bisnis khususnya dalam manajemen kualitas.

b. Tujuan Penelitian

Adapun tujuan dari penelitian ini adalah sebagai berikut : 1. Untuk mengetahui tingkat kepedulian manajemen terhadap penerapan TI. 2. Untuk mengetahui sejauh mana pengaruh TI di perusahaan pada visi, misi, rencana kerja, rencana strategi untuk mencapai tujuan perusahaan. 3 . Untuk memberikan rekomendasi perbaikan terhadap kinerja tata kelola TI yang telah berjalan saat ini agar lebih baik dalam mengontrol manajemen kualitas bila ditinjau dari domain Monitor and Evaluate pada COBIT 4.1.

c. Manfaat Penelitian Berdasarkan uraian latar belakang maka maksud dari penelitian ini adalah "Audit Tata Kelola TI Untuk Mengontol Manajemen Kualitas Menggunakan Cobit 4.1 di PT Nikkatsu Electric Works". Dengan dilakukannya audit tatakelola ini bermaksud untuk mengetahui kinerja dari tata kelola TI dan memperbaiki kinerja untuk mengontrol manajemen kualitas yang telah berjalan agar menjadi lebih baik

\section{B. TINJAUAN PUSTAKA}

\section{Audit Sistem Informasi}

Menurut Maniah \& Sri Lestari (2008) mengungkapkan bahwa Audit Sistem Informasi adalah proses untuk mengumpulkan dan mengevaluasi bukti dalam menentukan apakah sistem informasi telah dibangun sehingga memelihara integritas data, menjaga aset, membuat sasaran organisasi dapat tercapai secara efektif, dan menggunakan sumber daya yang efisien. Integritas data berhubungan dengan akurasi dan kelengkapan infonnasi demikian pula kesesuaiannya dengan standar. Sistem informasi yang efektif membawa organisasi untuk mencapai objektifnya dan sebuah sistem informasi yang efisien menggunakan sumber daya yang minimum dalam mencapai objektif yang diinginkan.

dari auditing disebut pernyataan pendapat (opini) mengenai kesesuaiannya antara asersi atau pernyataan tersebut dengan kriteria yang ditetapkan.

II. Pengertian Tata Kelola 
Tata kelola (Governance) merupakan turunan dari kata "government", yang artinya membuat kebijakan (policies) yang sejalan/selaras dengan keinginan/aspirasi masyarakat atau kontituen. Sedangkan penggunaan pengertian "governance" terhadap Teknologi Informasi (IT Governance) maksudnya adalah, penerapan kebijakan TI di dalam organisasi agar pemakaian TI (berikut pengadaan dan pelayanannya) diarahkan sesuai dengan tujuan organisasi tersebut[4].

\section{Pengertian Informasi}

Pengertian informasi adalah data yang diolah menjadi bentuk yang berguna bagi para pemakainya[8]. Sedangkan yang di maksud dengan informasi adalah data yang telah dirangkum atau di manipulasi dalam bentuk lain untuk tujuan pengambilan keputusan[9]. Sedangkan data itu sendiri merupakan fakta-fakta dan gambar mentahan yang akan di proses menjadi informasi[9].

e-ISSN : 2443-2229

\section{Pengertian Sistem Informasi}

Informasi merupakan komponen penting dalam suatu sistem. Informasi dibutuhkan bagi manajemen untuk pengambilan keputusan atau kebijakan. Sistem informasi merupakan suatu sistem yang tujuannya menghasilkan informasi [8]. Sistem Informasi (Information System) adalah sekumpulan komponen yang saling berhubungan, mengumpulkan atau mendapatkan, memproses, menyimpan dan mendistribusikan informasi untuk menunjang pengambilan keputusan dan pengawasan dalam suatu organisasi serta membantu manajer dalam mengambil keputusan[10].

\section{V.Pengertian Manajemen Kualitas Manajemen kualitas dalam konteks}

organisasi, bisa dikatakan merupakan sekumpulan kegiatan seperti merencanakankualitas, mengorganisasikan kualitas, mengendalikan dan mengevaluasi kualitas yang dilakukan oleh setiap fungsi manajemen yang ada dalam organisasi untuk meningkatkan kinerja dalam artian kualitas kerja dan hasil kerja [3]. Kualitas dalam era globalisasi telah menjadi harapan dan keinginan semua orang khususnya pelanggan.

Jurnal Teknik Informatika dan Sistem Informasi Volume 1 Nomor 3 Desember 2015

Keberhasilan organisasi untuk menjadikan manajemen kualitas sebagai unggulan daya saing harus mempunyai empat kriteria persyaratan :

1. Manajemen kualitas harus didasari oleh kesadaran akan kualitas dan dalam semua kegiatan harus selalu berorientasi pada kualitas, baik kualitas proses maupun kualitas produk.

2. Manajemen kualitas harus memberi inspirasi kepada karyawan.

3. Manajemen kualitas harus didasarkan pada pendekatan desentralisasi yang memberikan wewenang disemua tingkat, terutama digaris depan sehingga antusiasme keterlibatan karyawan untuk mencapai tujuan bersama menjadi kenyataan, bukan hanya slogan.

4. Manajemen kualitas harus diterapkan secara menyeluruh sehingga semua prinsip dan kebijaksanaan dapat mencapai setiap tingkat dalam organisasi [3].

Ada hubungan yang erat antara mutu produk (barang dan jasa), kepuasan pelanggan, dan laba perusahaan. Makin tinggi mutu suatu produk, makin tinggi pula kepuasan pelanggan dan pada waktu yang bersamaan akan mendukung harga yang tinggi dan seringkali biaya rendah. Oleh karena itu program perbaikan mutu bertujuan untuk meningkatkan laba [3]. 
VI. Pengertian Tata Kelola Teknologi Informasi

Pengertian tata kelola teknologi informasi menurut para ahli, diantaranya sebagai berikut :

1.Kapasitas organisasi untuk mengendalikan formulasi dan implementasi strategi teknologi informasi dan mengarahkan kepada kepentingan pencapaian daya saing korporasi [4].

2. Tata kelola teknologi informasi adalah pertanggungjawaban dewan direksi dan manajemen eksekutif. Hal ini, merupakan bagian yang terintegrasi dengan tata kelola perusahaan dan berisi kepemimpinan dan struktur serta proses organisasi yang menjamin bahwa organisasi teknologi informasi mengandung dan mendukung strategi serta tujuan bisnis[4].

3. Tata kelola teknologi informasi adalah penilaian kapasitas organisasi oleh dewan direksi, manajemen eksekutif, manajemen teknologi informasi untuk mengendalikan formulasi dan implementasi strategi teknologi informasi dalam rangka mendukung bisnisnya [4]. Dari ketiga definisi tersebut dapat disimpulkan bahwa yang dimaksud dengan tata kelola teknologi informasi adalah upaya menjamin pengelolaan teknologi informasi agar mendukung bahkan selaras dengan strategi bisnis suatu enterpriseyang dilakukan oleh dewan direksi, manajemen eksekutif, dan juga oleh manajemen teknologi informasi[4]. H. Cobit

"COBIT (Control Objectives for Information and Technology ) merupakan model yang didesain untuk mengendalikan fungsi TI. Model ini sebenarnya dikembangkan oleh Information System Audit and Control Foundation (ISACF), lembaga peneltian untuk Information Systems Audit and Control Assoction (ISACA). Tahun 1999 tugas ISAF untuk COBIT ditransfer ke IT Governance
Institute (ITGI), yang merupakan badan idependen di dalam ISACA"[12].

"COBIT (Control Objectives for Information and Technology) adalah kerangka dari best practices manajemen TI yang membantu organisasi untuk memaksimalkan keuntungan bisnis dari organisasi TI mereka."[5]. COBIT adalah sekumpulan dokumentasi best practice untuk IT governance yang dapat membantu auditor, pengguna (user) dan manajemen, untuk menjebatani gap anatara resiko bisnis, kebutuha control dan masalahmasalah teknis TI[6].

Objek Penelitian

Objek Penelitian Objek penelitian di lakukan di PT Nikkatsu Electric Work yang beralamatkan di jalan Cimuncang no. 70 Bandung. Dengan demikian yang menjadi topik penelitian ini adalah "Audit Tata kelola TIUntuk Mengontrol Manajemen Kualitas Menggunakan Cobit 4.1 pada PT Nikkatsu Electric Works".

C. Metode Pengumpulan Data Metode yang digunakan dalam pengumpulan datadata adalah sebagai berikut :

1. Studi Kepustakaan Penelitian ini dilakukan dengan cara mencari dan mengumpulkan data,sumber informasi, dan bahanbahan yang diperoleh dari buku, jurnal, artikel terkait dengan audit teknologi informasi menggunakan kerangka kerja Cobit 4.1.

2. Observasi Melakukan pengamatan secara langsung terhadap penerapan sistem teknologi informasi pada Inventoryserta penggunaan sistem informasi oleh user terkait.

3. Wawancara dan Kuesioner Untuk memperoleh informasi data data yang dibutuhkan, penulis melakukan wawancara dengan pihak yang 
Universitas Mitra Indonesia

berkompeten yaitu kepala bagian EDP dan Logistik.

J. Alat Bantu Analisis Perancangan Alat bantu analisis menggunakan metode pengukuran skala prioritas AHP dan pendekatan kerangka kerja Cobit 4.1 yaitu untuk merumuskan kinerja IT dan tingkat kematangan proses sebagai dasar pembuatan rekomendasi

\section{STUDI KASUS}

Pada PT Nikkatsu Electric Work. masih banyak yang harus di perbaiki dan dukungan kegiatan.

Dalam menunjang kegiatan tersebut, inventori sudah didukung oleh TI yang berupa suatu sistem informasi inventori, namun seiring berjalannya waktu sering terjadi keterlambatan dan kesalahan yang terjadi. Namun akar dari itu semua dikarenakan masih rendahnya tingkat kepedulian manajemen terhadap penggunaan TI di PT Nikkatsu Electric Works khususnya dalam mengontrol manajemen kualitas. Oleh karena itu, perlu dilakukan suatu kegiatan audit tatakelola dimana dilakukan agar diketahui seberapa besar tingkat kematangan di perusahaan pada proses pengawasan dan evaluasi kinerja TI. Lalu setalah itu dibuat rekomendasi yang dapat diberikan untuk meningkatkan kinerja tata kelola TI yang sedang berjalan saat ini agar lebih baik dalam mendukung proses bisnis khususnya dalam manajemen kualitas.

\section{DISKUSI}

Kami membahas berdiskusi mengenai studi kasus dari PT Nikkatsu Electric Work.

perusahaan yang memproduksi alatalat listrik seperti: Transformer, Ballast,
Devi Cantika

PL-adaptor, Lampu Hemat Energi (LHE) selain itu produk lainnya adalah stacking core Yamaha, Moric, dan Yasunaga. Dalam mencapai tujuan bisnisnya, perusahaan ini mempunyai faktor-faktor pendukung dalam setiap aktifitas proses bisnis yang berjalan, salah satunya adalah menjamin kualitas pada saat pembelian bahan baku, produksi, sampai bahan jadi Peranan yang paling besar dalam menjamin kualitas adalah departemen logistik.

Masih rendahnya tingkat kepedulian manajemen terhadap penggunaan TI di PT Nikkatsu Electric Works khususnya dalam mengontrol manajemen kualitas.

Lalu Belum adanya rekomendasi yang dapat diberikan untuk meningkatkan kinerja tata kelola TI yang sedang berjalan saat ini agar lebih baik dalam mendukung proses bisnis khususnya dalam manajemen kualitas.

Oleh karena itu, perlu dilakukan suatu kegiatan audit tatakelola dimana dilakukan agar diketahui seberapa besar tingkat kematangan di perusahaan pada proses pengawasan dan evaluasi kinerja TI. Lalu setalah itu dibuat rekomendasi yang dapat diberikan untuk meningkatkan kinerja tata kelola TI yang sedang berjalan saat ini agar lebih baik dalam mendukung proses bisnis khususnya dalam manajemen kualitas.

\section{E. KESIMPULAN}

Kesimpulan

Berdasarkan hasil penelitian, dapat disimpulkan

bahwa :

1. Tingkat kepedulian manajemen (management awareness) pada saat ini ada di angka 1,78 artinya, tingkat kepedulian manajemen terhadap TI 
masih rendah. Sehingga secara tidak langsungdapat mempengaruhi tingkat kematangan (maturity level) pada PT Nikkatsu Electric Works.

2.Tingkat kematangan pada ME 1 PT Nikkatsu Electric Works pada saat ini (asis) berada pada tingkat 2 (Repeatable but Intuitive) yang artinya adalah proses dikembangkan kedalam tahapan prosedurnya yang serupa namun tidak seluruhnya terdokumentasi dan tidak seluruhnya disosialisasikan kepada pelaksana.

3. Tingkat kematangan yang diharapkan pada ME 1 PT Nikkatsu Electric Works berada pada tingkat 4 (Managed and Measurable) yang artinya perusahaan menginginkan pengawasan dan evaluasi tata kelola TI telah distandarisasikan, didokumentasikan, dan dikomunikasikan serta diterapkan secara formal dan terintegrasi.

4. Terjadi kesenjangan yang cukup besar dari tingkat 2 menuju tingkat 4 . Kesenjangan ini sebagai alat bantu untuk membuat strategi yang perlu dilakukan. Strategi tersebut dilakukan peningkatan dalam aspek-aspek kesadaran dan komunikasi; kebjakan, standar, dan prosedur; alat dan otomasi; tanggung jawab; dan penetapan dan pencapaian tujuan.

\section{F. REFERENSI}

[1] PUTRA, Arie Setya; FEBRIANI, Ochi Marshella. Knowledge Management Online Application in PDAM Lampung Province. In: Prosiding International conference on Information Technology and Business (ICITB). 2018. P. 181-187.

[2] FEBRIANI, Ochi Marshella; PUTRA, Arie Setya. Sistem Informasi
Monitoring Inventori Barang Pada Balai Riset Standardisasi Industri Bandar Lampung. Jurnal Informatika, 2014, 13.1: 90-98

[3] Putra, A. S. (2018, July 9). 2018 Artikel Struktur Data , Audit dan Jaringan Komputer. Retrieved from osf.io/3uq8w

[4] Tresnawati. Risna, "Audit Sistem Informasi Pembayaran Tagihan Rekening Air Bulanan Dengan Menggunakan Kerangka Kerja COBIT 4.1 Pada Perusahaan Daerah Air Minum (PDAM) Kota Bandung”,S.Kom.,Program Studi Sistem Informasi, UNIKOM, Bandung,2014.

[5] Haag, S and Keen P,"Information Technology, Tomorrow's Advantage Today", McGraw-Hill, 1996. 